Check for updates

dkamerow@aafp.org

Cite this as: BMJ 2021;372:n85

http://dx.doi.org/10.1136/bmj.n85

Published: 13 January 2021

\title{
YANKEE DOODLING
}

\section{Immunized? There's an app for that}

\section{A "yellow card" for the digital age, or a means to a new social divide?}

Douglas Kamerow senior scholar, Robert Graham Center for policy studies in primary care, professor of family medicine, Georgetown University, and associate editor, The BMJ

If you're of a certain age, or if you travel to exotic places, you'll be familiar with the "yellow card." Issued by the World Health Organization originally for use in yellow fever epidemics, this folding, pocket sized card displays an individual's immunization history for international border crossings. Fast forward to 2021. Now we're digital, of course, so we need a mobile phone app to document whether we've been tested for-and soon, immunized against-covid-19. ${ }^{1}$

Ideally, we would have a universally adopted credential to securely document and share negative coronavirus tests and, ultimately, immunization status. This would facilitate the safe reopening of public transportation and venues where many people gather (such as sports arenas and concert halls). To this end, an international non-profit organization, the Commons Project, convened a meeting in July 2020, co-sponsored by the World Economic Forum and the Rockefeller Foundation. They're now at work testing an app called the CommonPass

(https://thecommonsproject.org/commonpass), which is intended to be "a secure and verifiable way [for travelers] to document their health status as they travel and cross borders."

United Airlines has tested the CommonPass on flights between the US and London and is reportedly planning to use the app regularly on some international flights, as are four other airlines. ${ }^{1}$ Currently, passengers download the app, get directed to an approved testing center and, after testing negative for coronavirus, receive a confirmation code to show before boarding. In the future, we are told the app will also securely display verified immunization status.

For-profit companies are also eager to enter this market. Clear, a US security company that uses biometric data to confirm people's identities at airports and other venues, is now documenting negative coronavirus tests for sports teams with its Health Pass app and has plans to validate immunizations when they become available (https://clearme.com/healthpass). Besides airports, Clear already operates at large sports arenas in the US. I've used it myself for expedited security clearance at baseball games in Washington, DC.

You can see where all this is heading. The availability of secure digital health credentials could speed reopening of offices, schools, and businesses. In the name of health security, we will evolve into a two class society: people who can document their covid immunity with an app, and those who can't. But what if you don't have a mobile phone? Or you don't have a good internet connection? Or the app isn't working for you? As long as you've got the magic ticket you get express entry onto your flight, into your office, to the football game, and maybe soon into the local pub. If not, you're out of luck.

Civil liberties advocates are starting to express concerns about the implications of immunity apps. ${ }^{1}$ The private companies-non-profit or for-profitproducing these apps are outside government control or verification. It is not hard to imagine possible bad outcomes from a future split between haves and have-nots: perhaps denial of access to public transportation, decreased job opportunities, and even housing discrimination.

Immunity apps seem to be a great idea in need of serious regulation. I would feel a lot better about them if some government agencies or WHO were leading this activity.

\section{Singer N. Vaccinated? Let's see it on the app. New York Times. 14 Dec 2020. https://www.nytimes.com/2020/12/13/technology/coronavirus- vaccine-apps.html.}

This article is made freely available for use in accordance with BMJ's website terms and conditions for the duration of the covid-19 pandemic or until otherwise determined by BMJ. You may use, download and print the article for any lawful, non-commercial purpose (including text and data mining) provided that all copyright notices and trade marks are retained. 